\title{
Bone-Protective Effects of Dried Plum in Postmenopausal Women: Efficacy and Possible Mechanisms
}

\author{
Bahram H. Arjmandi ${ }^{1,2, *}$, Sarah A. Johnson ${ }^{3}$, Shirin Pourafshar ${ }^{1,2}$, Negin Navaei ${ }^{1,2,4}$, \\ Kelli S. George ${ }^{1,2}$, Shirin Hooshmand ${ }^{5}$, Sheau C. Chai ${ }^{6}$ and Neda S. Akhavan ${ }^{1,2}$ \\ 1 Department of Nutrition, Food and Exercise Sciences, College of Human Sciences, Florida State University, \\ Tallahassee, FL 32306, USA; sp12r@my.fsu.edu (S.P.); negin.navaei@life.edu (N.N.); \\ ksg15c@my.fsu.edu (K.S.G.); nsa08@my.fsu.edu (N.S.A.) \\ 2 Center for Advancing Exercise and Nutrition Research on Aging (CAENRA), College of Human Sciences, \\ Florida State University, Tallahassee, FL 32306, USA \\ 3 Department of Food Science and Human Nutrition, College of Health and Human Sciences, Colorado State \\ University, Fort Collins, CO 80523, USA; Sarah.Johnson@colostate.edu \\ 4 Department of Nutrition, College of Graduate and Undergraduate Studies, Life University, Marietta, \\ GA 30060, USA \\ 5 School of Exercise and Nutritional Sciences, College of Health \& Human Services, \\ San Diego State University, San Diego, CA 92182, USA; shooshmand@mail.sdsu.edu \\ 6 Department of Behavioral Health and Nutrition, College of Health Sciences, University of Delaware, \\ Newark, DE 19716, USA; scchai@udel.edu \\ * Correspondence: barjmandi@fsu.edu; Tel.: +1-850-645-1517
}

Received: 15 April 2017; Accepted: 12 May 2017; Published: 14 May 2017

\begin{abstract}
Osteoporosis is an age-related chronic disease characterized by a loss of bone mass and quality, and is associated with an increased risk of fragility fractures. Postmenopausal women are at the greatest risk of developing osteoporosis due to the cessation in ovarian hormone production, which causes accelerated bone loss. As the demographic shifts to a more aged population, a growing number of postmenopausal women will be afflicted with osteoporosis. Certain lifestyle factors, including nutrition and exercise, are known to reduce the risk of developing osteoporosis and therefore play an important role in bone health. In terms of nutrition, accumulating evidence suggests that dried plum (Prunus domestica L.) is potentially an efficacious intervention for preventing and reversing bone mass and structural loss in an ovariectomized rat model of osteoporosis, as well as in osteopenic postmenopausal women. Here, we provide evidence supporting the efficacy of dried plum in preventing and reversing bone loss associated with ovarian hormone deficiency in rodent models and in humans. We end with the results of a recent follow-up study demonstrating that postmenopausal women who previously consumed $100 \mathrm{~g}$ dried plum per day during our one-year clinical trial conducted five years earlier retained bone mineral density to a greater extent than those receiving a comparative control. Additionally, we highlight the possible mechanisms of action by which bioactive compounds in dried plum exert bone-protective effects. Overall, the findings of our studies and others strongly suggest that dried plum in its whole form is a promising and efficacious functional food therapy for preventing bone loss in postmenopausal women, with the potential for long-lasting bone-protective effects.
\end{abstract}

Keywords: bioactive compounds; functional foods; menopause; nutrition; polyphenols; (poly)phenols; prune; osteopenia; osteoporosis 


\section{Introduction}

The postmenopausal period typically occupies one-third of a woman's life [1], and it is estimated that by the year 2020, more than 46 million women in the United States (U.S.) will be postmenopausal [2]. Menopause is associated with the development of numerous chronic diseases [3], due to an abrupt cessation of ovarian hormone production, namely estrogen. Osteoporosis is a chronic and debilitating age-related skeletal disease characterized by the loss of bone mass and a deterioration of the microstructural properties of bone, resulting in an increased propensity for fragility fractures [4]. Osteoporosis is responsible for more than 1.5 million fractures per year in the U.S., with most occurring in postmenopausal women [5]. Osteoporosis and its related bone fractures are a major public health concern as they are associated with increased morbidity and mortality, a poor quality of life, and a large economic burden [6,7]. Approximately 44 million men and women over the age of 50 have osteoporosis or low bone mass in the U.S. [3]. Diminished estrogen levels associated with menopause result in an initial phase of rapid bone loss, followed by a period of a slower deterioration of the skeleton [8]. This rapid phase of bone loss occurs within the first five to 10 years following the cessation of menses or the surgical removal of the ovaries [9]. As the demographic shifts to a more aged population, the prevalence and incidence of osteoporosis are likely to continue to increase, with affected individuals being at a greater risk of falls, fragility fractures, and therefore morbidity and mortality [3]. As such, therapeutic strategies that can delay, slow down, or prevent bone loss in aging individuals, and particularly in postmenopausal women, are critically needed.

Hormone replacement therapy is a logical therapeutic strategy for postmenopausal women since age-related chronic disease development typically begins after the cessation of ovarian hormone production. However, evidence from the Women's Health Initiative indicates that the risks associated with hormone replacement therapy outweigh its benefits, making the exploration of alternative therapies necessary [10]. Although the Food and Drug Administration has approved several anti-resorptive pharmacological agents such as bisphosphonates and denosumab, as well as the bone-forming pharmacological agent teriparatide, these drugs are associated with adverse side effects, are costly, and often have low compliance [11]. Therefore, it is imperative that safe and cost-effective therapeutic strategies, aside from medications, that can delay, slow down, or prevent bone loss in postmenopausal women be identified, investigated for efficacy, and disseminated for public use.

It is well-known that certain lifestyle factors, including diet and nutrition, play an important role in bone health. In fact, research has demonstrated that certain foods (i.e., functional foods) and their bioactive compounds, including nutrient and non-nutrient compounds, have bone-protective effects [12]. Of the functional foods investigated for their bone-protective properties, the most efficacious have typically been in the form of fruits and vegetables. The findings from our studies [13-15] and others [16,17] suggest that dried plum (Prunus domestica L.) is the most effective in preventing and reversing bone loss among the fruits and vegetables investigated. This has also been demonstrated by Mühlbauer et al. [18,19], who examined the effects of 60 fruits and vegetables on bone. Their findings indicated that onion and dried plum had the most potent bone-protective effects. Though the consumption of fruits and vegetables for general health and well-being is encouraged, in terms of bone health, not all fruits and vegetables offer the same benefits. For instance, while certain fruits such as dried plum and to some extent blueberries exert bone-protective effects [20], in our observations [14], the same may not be true for other fruits such as raisins and dates. We are using a conditional term for the effectiveness of blueberry on bone, because our findings [20], as well as those of Zhang et al. [21,22], are preliminary at this point and await confirmation in human studies. The reasons for these discrepancies in the efficacy among fruits and vegetables remain unknown.

Due to the bioactive compound content and composition of dried plum, as well as promising preclinical and clinical research findings, dried plum has been and continues to be investigated as a potential functional food with respect to bone health. Numerous studies in cells, rodent models of postmenopausal osteoporosis, and postmenopausal women have demonstrated its efficacy and have identified possible mechanisms of action. Studies have aimed to identify specific bioactive compounds 
in dried plum responsible for its bone-protective properties. The present review provides an overview of dried plum, including its nutritional and bioactive compound composition, and provides evidence from preclinical and clinical studies supporting the efficacy of dried plum in preventing and reversing bone loss in postmenopausal women, as well as evidence to support possible mechanisms of action, and bioactive compounds in dried plum responsible for its efficacy. Additionally, gaps in the research and promising new areas of investigation are discussed.

A literature search was performed using the PubMed database and Google Scholar. The following keywords, alone and in combination, were used: bone, dried plum, menopause, osteopenia, osteoporosis, ovariectomy, ovariectomized, plum, postmenopausal, and prune. Preclinical studies using rodent models of postmenopausal osteoporosis and clinical trials with postmenopausal women were included in this review.

\section{Dried Plum: A Promising Functional Food for Bone Health}

The U.S., primarily California, is a major producer of dried plum, with approximately $99 \%$ of the U.S. and $40 \%$ of the world supply grown in California. Dried plum was previously referred to as prunes until a formal name change was requested and approved by the Food and Drug Administration in 2001 [23]. It is most commonly known for its effects on gastrointestinal motility and research has been and continues to be conducted with respect to gastrointestinal health to support these observations. In addition, dried plum has been investigated for its antimicrobial, cancer-preventive, cardiometabolic, neurological, and bone-protective effects [24,25].

To date, the most notable research has been in the area of bone metabolism and health. The unique ability of dried plum to promote bone health is likely related to its bioactive compound composition. Dried plum is rich in nutrient bioactive compounds including dietary fiber, vitamin $\mathrm{K}$, boron, copper, magnesium, manganese, among others, many of which are known to positively influence bone [23-25]. It is also rich in non-nutrient bioactive compounds including (poly)phenols such as chlorogenic acids (e.g., chlorogenic acid, neochlorogenic acid, cryptochlorogenic acid) and proanthocyanidins [24,25]. Dried plum has been ranked as having one of the highest oxygen radical absorbance capacities among the commonly consumed fruits and vegetables. It has been suggested that this is likely to be primarily due to its (poly)phenolic compound composition and content, as dried plum is low in ascorbic acid, carotenoids, and vitamin E [23]. In addition, previous research has demonstrated that phenolic compounds, including those found in dried plum, exert bone-protective effects and profoundly affect bone metabolism [25]. For instance, rutin, a flavonoid commonly found in plums and various berries, has been reported to inhibit ovariectomy-induced bone loss in a rat model of osteoporosis [26]. Nonetheless, the question still remains as to which bioactive component(s) of dried plum are responsible for its bone-protective effects. The answer may simply be that the whole fruit is more efficacious than its isolated components due to the additive and/or synergistic effects of these components within the food matrix.

\section{Dried Plum and Bone Health: Rodent Models of Postmenopausal Osteoporosis}

Previous studies investigating the role of dried plum on bone health in rodent models of postmenopausal osteoporosis are summarized in Table 1. Our laboratory [27] was the first to report the bone-protective effects of dried plum both in general, and specifically in an established rat model of postmenopausal osteoporosis [28]. We showed that ovariectomy led to significant declines in the bone mineral density (BMD) of the 4th lumbar vertebrae and femurs, as well as a decrease in the tibial trabecular bone area compared to sham-operated (Sham) rats. However, ovariectomized (Ovx) rats that received $25 \%$ of the diet as dried plum for 45 days did not lose bone, while those receiving $5 \%$ of the diet as dried plum lost bone similarly to Ovx rats not receiving dried plum (Figure 1). Despite this, we also found that dried plum dose-dependently increased circulating insulin-like growth factor-I (IGF-I) levels, while having no effect on tartrate-resistant acid phosphatase-5b (TRAP-5b) levels. At that time, TRAP-5b was considered to be a biomarker of bone resorption. Therefore, these results suggested 
that dried plum prevented bone loss, in part, by increasing the rate of bone formation, but not through inhibiting bone resorption.

(A)

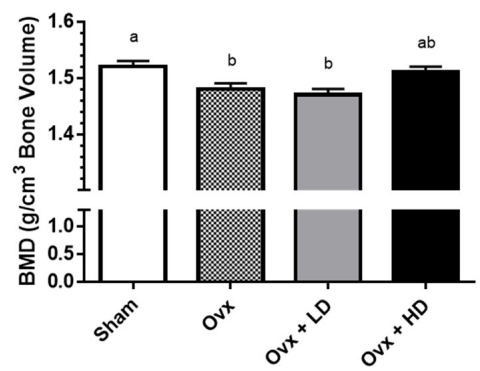

(B)

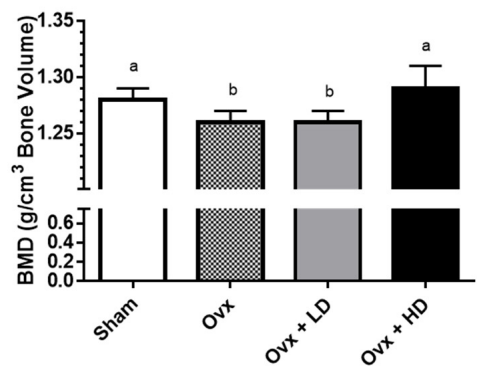

Figure 1. (A) Effects of ovariectomy and dried plum on bone density of right femur; (B) Effects of ovariectomy and dried plum on bone density of 4 th lumbar spine. Bars represent mean \pm standard error of the mean. Bars that do not share the same letters are significantly $(p<0.05)$ different from each other. BMD, bone mineral density; HD, high dose (25\%) dried plum; LD, low dose (5\%) dried plum; Ovx, ovariectomized; Sham, sham-operated.

We next asked the question: could the addition of dried plum to the diet restore bone mass after bone loss has occurred? Toward this end, our laboratory [27] used an Ovx rat model of postmenopausal osteoporosis to evaluate the ability of dried plum at different doses to reverse bone loss. In this study, 90-day-old female Sprague-Dawley rats were divided into six groups: Sham control, Ovx control, Ovx $+17 \beta$-estradiol $\left(\mathrm{E}_{2}\right), \mathrm{Ovx}+5 \%$ of the diet as dried plum, Ovx $+15 \%$ of the diet as dried plum, and $\mathrm{Ovx}+25 \%$ of the diet as dried plum for 60 days. Interestingly, the consumption of all doses of dried plum (5\%, 15\%, and 25\%) effectively restored femoral and tibial BMD to the same extent as $\mathrm{E}_{2}$, while only the group receiving $25 \%$ dried plum showed the restoration of 4 th lumbar BMD (Figure 2). At the time in which this study was conducted, the loss of bone volume accompanied by the loss of trabecular connectivity was generally believed to be an irreversible process [29]. To our knowledge, our study was the first to demonstrate that an agent of any kind could reverse the loss of trabecular microstructures including the bone volume/total volume, connectivity density, trabecular number, trabecular separation, and structure model index (Figure 3).

(A)

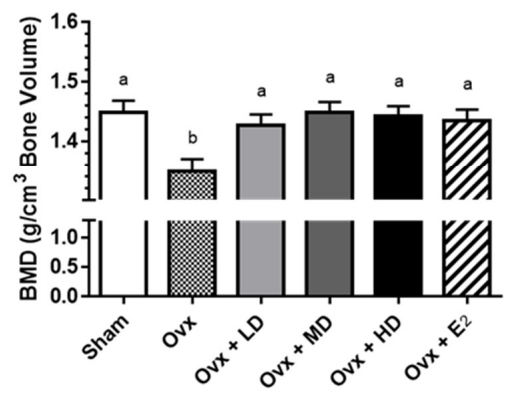

(B)

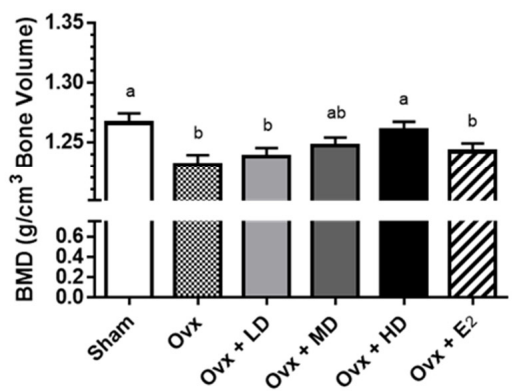

Figure 2. (A) Effects of ovariectomy, dried plum, and estrogen on bone density of right femur; (B) Effects ovariectomy, dried plum, and estrogen on bone density of 4 th lumbar spine. Bars represent mean \pm standard error of the mean. Bars that do not share the same letters are significantly $(p<0.05)$ different from each other. BMD, bone mineral density; $E_{2}, 17 \beta$-estradiol, LD, low dose (5\%) dried plum; high dose (25\%) dried plum; MD, medium dose (15\%) dried plum; Ovx, ovariectomized; Sham, sham-operated. 
Sham

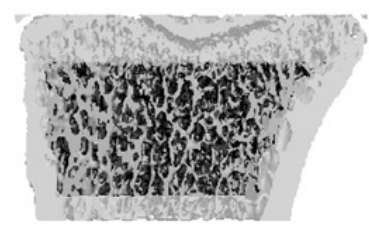

Ovx $+M D$

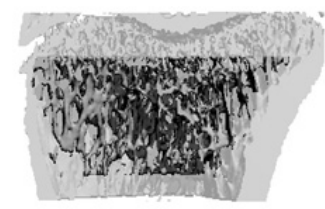

Ovx
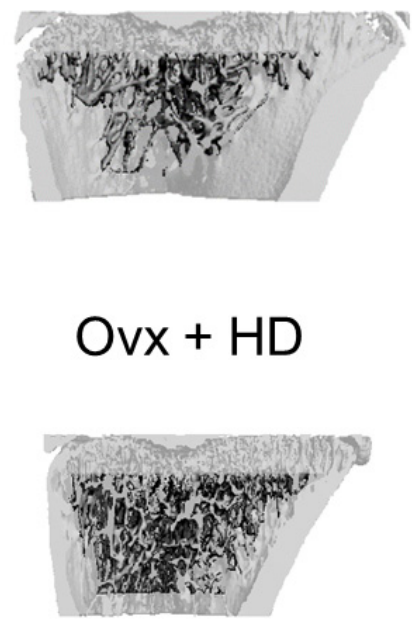

Ovx + LD

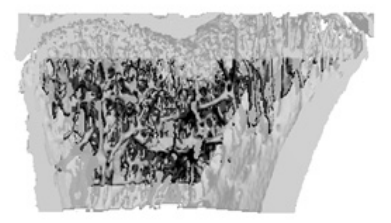

$\mathrm{Ovx}+\mathrm{E}_{2}$

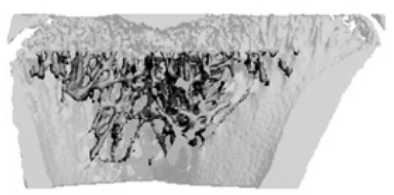

Figure 3. Representative images of proximal tibia demonstrating the effect of ovariectomy, dried plum, and estrogen on trabecular bone structure. $\mathrm{E}_{2}, 17 \beta$-estradiol; LD, high dose (25\%) dried plum; low dose $(5 \%)$ dried plum; MD, medium dose (15\%) dried plum, Ovx, ovariectomized; Sham, sham-operated.

We next sought to evaluate the efficacy of several potentially bone-protective functional foods and bioactive compounds (i.e., dried plum, figs, dates, raisins, blueberries, dried plum (poly)phenols, fructooligosaccharides (FOS), and $\beta$-hydroxy- $\beta$-methylbutyrate, alone and in combination, on the bone mass and quality in Ovx rats after bone loss had already occurred [14]. Our findings revealed that the group receiving $5 \%$ FOS $+7.5 \%$ dried plum in their diet had the greatest reversal of BMD loss in the right femur and 4th lumbar spine, 4th lumbar spine calcium loss, and trabecular separation. Interestingly, none of the treatments altered the serum or urinary markers of bone turnover. The findings of this study suggest that the addition of prebiotic FOS to dried plum improves its efficacy in restoring bone mass and quality after bone loss has occurred. Although the mechanisms remain unknown, FOS has been demonstrated to increase the absorption of minerals, including calcium and magnesium, in the colon [30]. Additionally, considering that FOS is a prebiotic, it is likely that the combination of FOS and dried plum worked through gut microbiota-related mechanisms including an increase in mineral absorption. Importantly, the dose of dried plum (i.e., $7.5 \%$ of the diet) that was efficacious in combination with FOS was lower than what was previously found to be effective. This suggests that the addition of FOS to dried plum may improve the efficacy of dried plum and should be further investigated. These findings will be particularly important if they can be translated to humans, as it could be a novel strategy for reducing the amount of dried plum an individual would need to consume on a daily basis to achieve the same outcomes.

In addition to demonstrating the bone-protective effects of dried plum alone and in combination with FOS, we have also demonstrated in numerous studies that soy is a potentially efficacious functional food for promoting bone health [31-35]. We therefore sought to determine the efficacy of a soy-based diet in combination with $7.5 \%$ dried plum, $5 \%$ FOS, or $7.5 \%$ dried plum $+5 \%$ FOS on reversing bone loss in a rat model of postmenopausal osteoporosis. We found that the combination of a soy-based diet with dried plum, FOS, or both, significantly improved the whole body BMD and femoral BMD, while the combination of all components (i.e., soy, dried plum, and FOS) had the most pronounced effect on lumbar BMD [15]. All interventions were noted to improve the biomechanical properties of bone, as demonstrated by the increased ultimate load. The serum biomarker results suggest that these improvements may have been due, in part, to their ability to enhance bone formation and reduce bone resorption, as shown by increases in blood alkaline phosphatase (ALP) and decreased urinary deoxypyridinoline (Dpd). 
Other investigators have also demonstrated the bone-protective effects of dried plum in rodent models postmenopausal osteoporosis. Rendina et al. [16] showed that feeding $25 \%$ of the diet as dried plum for four weeks to female Ovx C57BL/6J mice prevented the loss of BMD and bone mineral content (BMC) of the spine, and trabecular microarchitectural properties of the vertebrae and proximal tibiae, resulting in greater bone strength and stiffness in the vertebrae. Additionally, feeding dried plum in the diet at $15 \%$ and $25 \%$ doses restored myeloid and lymphoid levels to that of the sham-operated mice and suppressed ex vivo concanavalin A stimulated lymphocyte tumor necrosis factor- $\alpha$ production in splenocytes.

In another study, Rendina et al. [36] reported the results of a study comparing the bone-protective effects of dried plum with other fruits (i.e., dried apple, apricot, grape, and mango) in Ovx C57BL/ 6 mice over an eight-week period. They demonstrated that dried plum had superior anabolic effects on the trabecular bone microarchitectural properties of the vertebrae, was able to prevent tibial bone loss, and restored the trabecular biomechanical properties of the spine when compared with the other fruits. In addition, dried plum was more efficacious than the other fruits in enhancing plasma glutathione peroxidase activity, downregulating osteoclast differentiation, upregulating osteoblast activity, and suppressing Ovx-induced apoptosis.

Smith et al. [37] reported the findings of a study out of the same laboratory in which they compared the effects of six weeks of dried plum supplementation to treatment with parathyroid hormone (PTH). Treatment with dried plum at doses of $15 \%$ and $25 \%$ in the diet restored the whole body and femoral BMD to that of the Sham group and improved the trabecular bone volume and cortical thickness. Systemic blood biomarkers of bone metabolism (i.e., $N$-terminal procollagen type 1 and Dpd) were reduced, indicating a reduction in bone turnover. Dynamic bone histomorphometric analysis of the tibial metaphysis revealed that dried plum restored the Ovx-induced increase in the cancellous bone formation rate and mineralizing surface to that of the Sham group. Dried plum also upregulated the gene expression of bone morphogenetic protein 2, a regulator of osteogenesis, and IGF-I while downregulating the nuclear factor $T$ cell activator 1 , a transcription factor involved in the regulation of osteoclast differentiation. Compared with that of the effects of PTH on bone, dried plum reduced the rate of bone turnover, rather than increasing the rate of bone formation.

In summary, our data and others strongly suggest that dried plum is an efficacious functional food for preventing and reversing the loss of bone mass and structural properties in a rat model of postmenopausal osteoporosis. We have also shown that dried plum dose-dependently increases systemic and local indices of bone formation, e.g., serum and mRNA levels of ALP. These findings suggest that dried plum prevents and reverses bone loss, primarily through enhanced bone formation. 
Table 1. Preclinical studies investigating the role of dried plum on bone health in rodent models of postmenopausal osteoporosis.

\begin{tabular}{|c|c|c|c|c|c|c|}
\hline Reference & Model & Number & Groups & Duration & Primary Outcomes & Primary Findings \\
\hline $\begin{array}{l}\text { Arjmandi et al., } \\
2001 \text { [27] }\end{array}$ & $\begin{array}{l}\text { Sham and Ovx female } \\
\quad 90 \text {-day old } \\
\text { Sprague-Dawley rats }\end{array}$ & 48 & $\begin{array}{l}\text { (1) Sham control, } \\
\text { (2) Ovx control, } \\
\text { (3) Ovx }+5 \% \text { dried plum, } \\
\text { or (4) Ovx }+25 \% \text { dried plum }\end{array}$ & 45 days & $\begin{array}{l}\text { BMD and \% mineral content of right femur and } \\
\text { 4th lumbar vertebrae; trabecular total area and } \\
\text { bone area; cortical total area, bone area, marrow } \\
\text { space, endosteal perimeter, and periosteal } \\
\text { perimeter; serum ALP, TRAP, and IGF-1 }\end{array}$ & $\begin{array}{l}\text { Compared to Ovx control: } \\
\text { 4th lumbar vertebrae and femur BMD and trabecular bone area were } \\
\text { significantly } \uparrow \text { in the } 25 \% \text { dried plum group }\end{array}$ \\
\hline $\begin{array}{l}\text { Deyhim et al., } \\
2005 \text { [38] }\end{array}$ & $\begin{array}{l}\text { Sham and Ovx female } \\
\quad 90 \text {-day old } \\
\text { Sprague-Dawley rats }\end{array}$ & 80 & $\begin{array}{l}\text { (1) Sham control, } \\
\text { (2) Ovx control, } \\
\text { (3) Ovx }+17 \beta \text {-estradiol, } \\
\text { (4) Ovx }+5 \% \text { dried plum, } \\
\text { (5) Ovx }+15 \% \text { dried plum, } \\
\text { (6) Ovx }+25 \% \text { dried plum }\end{array}$ & 60 days & $\begin{array}{l}\text { BMD of femur, left tibiae, and } 4 \text { th lumbar; } \\
\text { biomechanical properties (length, cortical area, } \\
\text { unit yield force, and unit ultimate force); } \\
\text { trabecular microarchitectural properties (BV/TV), } \\
\text { Tb N, Tb S, Tb Th, ConnDens, SMI); serum IGF-1, } \\
\text { ALP, and TRAP; urinary Dpd }\end{array}$ & $\begin{array}{l}\text { Compared to Ovx control: } \\
\text { Femur and tibia BMD were } \uparrow \text { in all dried plum groups, } 4 \text { th lumbar BMD } \\
\text { tended to be significantly and was significantly } \uparrow \text { in the } 15 \% \text { and } 25 \% \text { dried } \\
\text { plum groups, respectively; unit yield force tended to be significantly } \uparrow \text { in all } \\
\text { dried plum groups; } \mathrm{S} S \text { was significantly } \uparrow \text { in all dried plum groups while } \\
\text { Tb } N \text { and Tb Th were significantly } \uparrow \text { in } 15 \% \text { and } 25 \% \text { dried plum groups and } \\
\text { BV/TV and ConnDens were significantly } \uparrow \text { in } 25 \% \text { dried plum group; urinary } \\
\text { Dpd tended to be significantly } \downarrow \text { in all dried plum groups }\end{array}$ \\
\hline $\begin{array}{l}\text { Arjmandi et al., } \\
2010 \text { [14] }\end{array}$ & $\begin{array}{c}\text { Sham and Ovx female } \\
90 \text {-day old } \\
\text { Sprague-Dawley rats }\end{array}$ & 180 & $\begin{array}{l}\text { (1) Sham control, } \\
\text { (2) Ovx control, } \\
\text { (3) Ovx }+2 \% \text { FOS, } \\
\text { (4) Ovx }+5 \% \text { FOS }+7.5 \% \text { dried plum, } \\
\text { (5) Ovx }+2 \% \text { FOS }+5 \% \text { dried plum, } \\
\text { (6) Ovx }+2 \% \text { FOS + dried plum } \\
\text { polyphenols, } \\
\text { (7) Ovx }+2 \% \text { FOS + dried plum juice, } \\
\text { (8) Ovx }+2 \% \text { FOS + dried plum puree, } \\
\text { or (9) Ovx }+2 \% \text { FOS + dried plum } \\
\text { pulp } / \text { skins }\end{array}$ & 60 days & $\begin{array}{l}\text { BMD and BMC of whole body, right femur, and } \\
\text { 4th lumbar vertebrae; bone histomorphometric } \\
\text { parameters (BV/TV, Tb N, Tb S, Tb Th, } \\
\text { ConnDens, and SMI); } 4 \text { th lumbar calcium content; } \\
\text { serum osteocalcin and IGF-1; serum and urinary } \\
\text { calcium, magnesium, and phosphorus; urinary } \\
\text { Dpd }\end{array}$ & $\begin{array}{l}\text { Compared to Ovx control: } \\
\text { 4th lumbar vertebrae and femur BMD were significantly } \uparrow \text { in } 5 \% \text { FOS }+7.5 \% \\
\text { dried plum group with tendency to significantly } \downarrow \text { loss of lumbar vertebrae } \\
\text { calcium, and significantly } \downarrow \text { trabecular separation }\end{array}$ \\
\hline $\begin{array}{l}\text { Johnson et al., } \\
2011 \text { [15] }\end{array}$ & $\begin{array}{l}\text { Sham and Ovx female } \\
\quad 90 \text {-day old } \\
\text { Sprague-Dawley rats }\end{array}$ & 72 & $\begin{array}{l}\text { (1) Sham control, } \\
\text { (2) Ovx control, } \\
\text { (3) Ovx + soy, } \\
\text { (4) Ovx + soy + dried plum, } \\
\text { Ovx + soy + FOS, } \\
\text { or (5) Ovx + soy + dried plum + FOS }\end{array}$ & 60 days & $\begin{array}{l}\text { BMD and BMC of the whole body, right femur, } \\
\text { and } 4 \text { th lumbar vertebrae; femoral strength; bone } \\
\text { histomorphometric parameters (BV/TV, Tb N, Tb } \\
\text { S, Tb Th, and MS/BS); serum total ALP; urinary } \\
\text { creatinine and Dpd }\end{array}$ & $\begin{array}{l}\text { Compared to Ovx control: } \\
\text { Whole body and } 4 \text { th lumbar BMD tended to be significantly } \uparrow \text { in Ovx }+ \text { soy } \\
\text { dried plum group and was significantly increased in Ovx }+ \text { soy }+ \text { dried plum } \\
+ \text { FOS group, and right femur BMD was significantly } \uparrow ; \text { Th Th tended to be } \\
\text { significantly } \uparrow \text { and Tb Sp, and MS } / \text { BS tended to be significantly } \downarrow \text { in Ovx }+ \\
\text { soy + dried plum }+ \text { FOS group; serum ALP and urinary Dpd tended to be } \\
\text { significantly } \downarrow \text { in Ovx }+ \text { soy }+ \text { dried plum group and urinary Dpd was } \\
\text { significantly } \downarrow \text { in Ovx }+ \text { soy }+ \text { dried plum + FOS group }\end{array}$ \\
\hline $\begin{array}{l}\text { Rendina et al., } \\
2012 \text { [16] }\end{array}$ & $\begin{array}{l}\text { Sham and Ovx female } \\
90 \text {-day old } \\
\text { C57BL/6J mice }\end{array}$ & 59 & $\begin{array}{l}\text { (1) Sham control, } \\
\text { (2) Ovx control, } \\
\text { (3) Ovx }+5 \% \text { dried plum, } \\
\text { (4) Ovx }+15 \% \text { dried plum, } \\
\text { (5) Ovx }+25 \% \text { dried plum }\end{array}$ & 4 weeks & $\begin{array}{l}\text { BMA, BMC, and BMD of the 4th to 5th lumbar } \\
\text { vertebrae; bone microarchitecture parameters of } \\
\text { tibia and thth lumbar vertebrae (BV/TV, Tb N, Tb } \\
\text { S, Tb Th, ConnDens, and SMI); biomechanical } \\
\text { properties of trabecular bone (total force, stiffness, } \\
\text { size-independent stifffesses, and Von Mises } \\
\text { stresses); plasma PINP and IGF-1; Runx2, } \\
\text { osteocalcin, and NFATc1 bone gene expression }\end{array}$ & 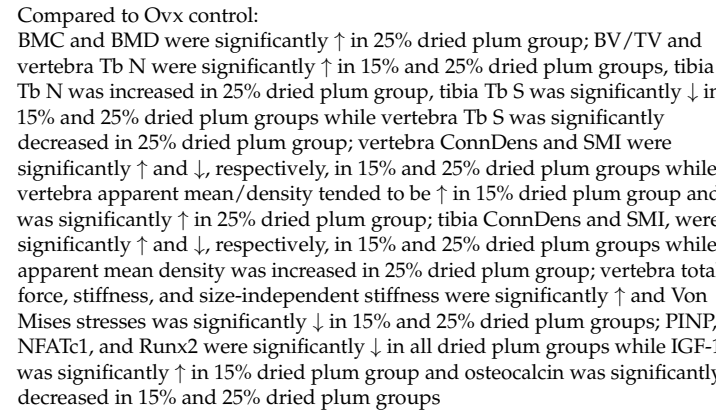 \\
\hline
\end{tabular}


Table 1. Cont.

\begin{tabular}{|c|c|c|c|c|c|c|}
\hline Reference & Model & Number & Groups & Duration & Primary Outcomes & $\begin{array}{l}\text { Primary Findings } \\
\end{array}$ \\
\hline $\begin{array}{l}\text { Rendina et al., } \\
\quad 2013[36]\end{array}$ & $\begin{array}{l}\text { Sham and Ovx female } \\
\text { 90-day old } \\
\text { C57BL/6J mice }\end{array}$ & 68 & $\begin{array}{l}\text { (1) Sham control, } \\
\text { (2) Ovx control, } \\
\text { (3) Ovx }+25 \% \text { dried plum, } \\
\text { (4) Ovx }+25 \% \text { dried apple, } \\
\text { (5) Ovx }+25 \% \text { dried apricot, } \\
\text { (6) Ovx }+25 \% \text { dried grape, } \\
\text { (7) Ovx }+25 \% \text { dried mango }\end{array}$ & 8 weeks & $\begin{array}{l}\text { BMA, BMC, and BMD of the whole body and 4th } \\
\text { and 5th lumbar vertebrae; bone microarchitecture } \\
\text { parameters of tibia and 4th lumbar vertebrae } \\
\text { (BV/TV, Tb N, Th S, Tb Th, ConnDens, SMI, and } \\
\text { trabecular density); biomechanical properties of } \\
\text { trabecular bone (total force, stiffness, } \\
\text { size-independent stiffness); plasma G Gx; bone } \\
\text { marrow gene expression of NFATc1, Colla1, ALP, } \\
\text { osteocalcin, Bak1; flushed femur expression of } \\
\text { Bak1, Casp3, Casp9 }\end{array}$ & 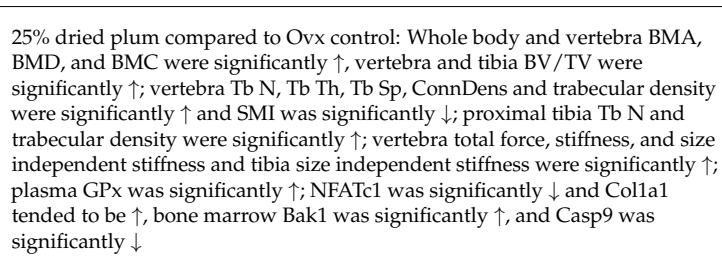 \\
\hline $\begin{array}{l}\text { Smith et al., } \\
2014[37]\end{array}$ & $\begin{array}{l}\text { Sham and Ovx female } \\
\text { 6-month old } \\
\text { Sprague-Dawley rats }\end{array}$ & 84 & $\begin{array}{l}\text { (1) Sham control, } \\
\text { (2) Ovx control, } \\
\text { (3) Ovx }+5 \% \text { dried plum, } \\
\text { (4) Ovx }+15 \% \text { dried plum, } \\
\text { (5) Ovx }+25 \% \text { dried plum, } \\
\text { (6) Ovx }+ \text { PTH }\end{array}$ & 6 weeks & $\begin{array}{l}\text { BMA, BMC, and BMD of the whole body, femur, } \\
\text { and 4th and 5th lumbar vertebrae; bone } \\
\text { microarchitecture parameters of tibia and 4th } \\
\text { lumbar vertebrae (BV/TV, Tb N, Tb S, Tb Th, } \\
\text { ConnDens, and SMI); dynamic bone } \\
\text { histomorphometry (proximal tibia metaphysis } \\
\text { BFR, MS/BS, and MAR; tibial cancellous } \\
\text { MS//bone area, and BFR//BV; tibial cortical bone } \\
\text { periosteal BF, periosteal MS, periosteal MAR, } \\
\text { endocortical BFR, endocortical MS, and } \\
\text { endocortical MAR), plasma PINP; urinary Dpd; } \\
\text { bone gene expression of NFATT1, Colla1, ALP, } \\
\text { osteocalcin, Runx2, BMP } 2 \text { and 4, IFG-1, } \\
\text { RANKL, OPG }\end{array}$ & 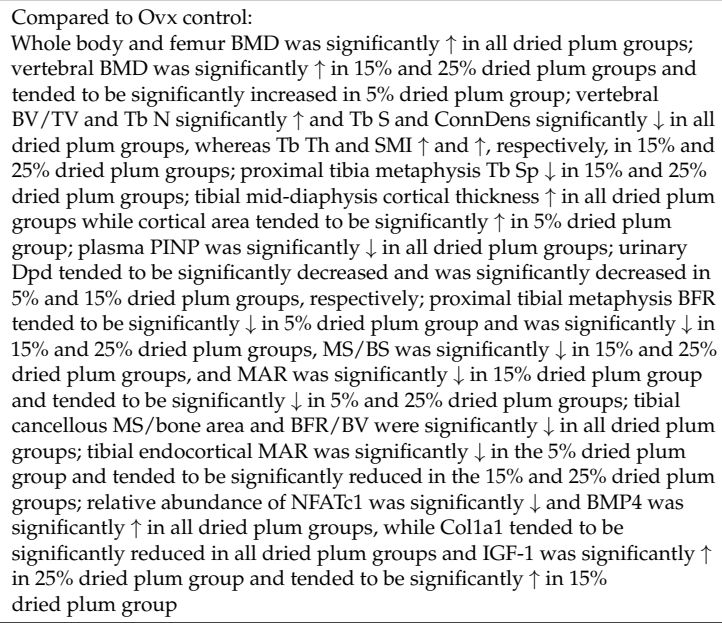 \\
\hline $\begin{array}{l}\text { Pawlowski et al., } \\
\quad 2014[39]\end{array}$ & $\begin{array}{c}\text { Ovx female } \\
\text { 3-month old } \\
\text { Sprague-Dawley rats }\end{array}$ & 44 & $\begin{array}{l}\text { (1) Control, } \\
\text { (2) grape seed extract-high, } \\
\text { (3) grape seed extract-low, } \\
\text { (4) blueberry-high, } \\
\text { (5) blueberry-low, } \\
\text { (6) dried plum-high, } \\
\text { (7) dried plum-low, } \\
\text { (8) grape-high, } \\
\text { (9) grape-low, } \\
\text { (10) resveratrol-high, } \\
\text { (11) resveratrol-low, } \\
\text { (12) soy isoflavon--glycosylated, } \\
\text { (13) soy isoflavone-genistein aglycone }\end{array}$ & 10 days & $\begin{array}{l}\text { Urine calcium ( }{ }^{45} \mathrm{Ca} \text { and total calcium); serum } \\
\text { BALP; urinary NTx }\end{array}$ & $\begin{array}{l}\text { Bone calcium retention was significantly } \uparrow \text { in dried plum-high group } \\
\text { compared to baseline }\end{array}$ \\
\hline
\end{tabular}


Table 1. Cont

Reference

Mode

\begin{abstract}
Number
\end{abstract}
Groups

Duration

Primary Outcomes

\section{(1) Sham control,}

(3) high chlorogenic acid dried plum

Léotoing et al., Ovx female 5-mont ld Wistar rats

84

(6) low chlorogenic acid

dried plum juice,

(7) low chlorogenic aci
dried plum + fiber
Total femoral BMD, metaphyseal BMD, and

90 days

CPII, CTX-II, and CRI; urinary Dpd and

calcium: BR

\section{Compared to Ovx control:}

Primary Findings

Total femoral BMD and metaphyseal BMD were significantly $\uparrow$ in low

juice group and tended to be significantly $\uparrow$ in all other dried plum groups;

diaphyseal BMD was significantly $\uparrow$ in high chlorogenic acid dried plum, low

chlorogenic acid dried plum + fiber and the low chlorogenic acid dried plum

juice groups; total BMC was significantly $\uparrow$ in all low chlorogenic acid dried

plum groups: blood osteocalcin was significantly $\downarrow$ in high chlorogenic acid dried plum, low chlorogenic acid dried plum + fiber, and low chlorogenic acid dried plum juice groups and tended to be significantly $\downarrow$ in the other dried plum groups; urinary Dpd was significantly $\downarrow$ in low chlorogenic acid dried plum + fiber and low chlorogenic acid dried plum juice groups and tended to be significantly $\downarrow$ in the other dried plum groups, $B$ te tended to be chlorogenic acid dried plum groups; all groups had significantly $\uparrow$ calciurea CPII and CRI were significantly $\uparrow$ in high chlorogenic acid dried plum group

BALP, bone alkaline phosphatase; BMA, bone mineral area; BMC, bone mineral content; BMD, bone mineral density; BFR, bone formation rate; BMP, bone morphogenetic proteins; $\mathrm{BRI}$, bone remodeling index; $\mathrm{BSAP}$, bone-specific alkaline phosphatase; $\mathrm{BV} / \mathrm{TV}$, bone volume to total volume ratio; ${ }^{45} \mathrm{Ca}$, calcium- 45 ; Colla1, type 1 collagen; ConnDens, connectivity density; CPII, C-propeptide of type II collagen; CRI, cartilage remodeling index; CTX-II, C-terminal telopeptides of type II collagen; Dpd, deoxypyridinoline; HP, helical peptide; IGF-1, insulin-like growth factor-1, IGFBP-3, insulin-like growth factor binding protein-3; IL-6, interleukin-6; MAR, mineral apposition rate; MS, mineralizing surface; MS/BS, mineral surface as percent of bone surface; NFATc1, nuclear factor of activated T cells; NTx, cross-linked N-telopeptides of type 1 collagen; OPG, osteoprotegerin; PINP, N-terminal propeptide of type 1 procollagen; $\mathrm{PTH}$, parathyroid hormone; RANKL, receptor activator of nuclear factor kappa-B ligand; Runx2, runt-related protein 2; Tb N, trabecular number; Tb Sp, trabecular separation $\mathrm{Tb}$ Th, trabecular thickness; TRAP, tartrate-resistant acid phosphatase; TNF- $\alpha$, tumor necrosis factor-alpha; Ovx, ovariectomized; Sham, sham-operated; SMI, structural model index. 


\section{Dried Plum and Bone Health: Clinical Trials in Postmenopausal Women}

Previously conducted clinical trials investigating the role of dried plum on bone health in postmenopausal women are summarized in Table 2. To our knowledge, our laboratory was the first to evaluate the bone-protective properties of dried plum in humans. Initially, we reported the findings of a three-month clinical trial evaluating the efficacy of dried plum versus dried apple (comparative control) on the biomarkers of bone formation in postmenopausal women [41]. Here, we showed that the consumption of $100 \mathrm{~g}$ /day dried plum significantly increased the serum markers of bone formation, namely total ALP, bone-specific ALP (BALP), and IGF-1 by 12,6 , and $17 \%$, respectively. The increase in BALP is important as studies have shown that clinically relevant doses of bone-forming agents such as sodium fluoride, growth hormone, and PTH take several months to moderately increase the serum levels of BALP [42]. Interestingly, the serum and urinary biomarkers of bone resorption were not affected by either intervention. These observations further support our hypothesis that dried plum prevents and reverses bone loss through enhanced bone formation.

To evaluate whether a longer treatment period would lead to an improvement in bone mass, we conducted a one-year clinical trial comparing the effects of the daily consumption of $100 \mathrm{~g}$ dried plum to $75 \mathrm{~g}$ dried apple (comparative control) on BMD and the biomarkers of bone turnover in 100 osteopenic postmenopausal women. We found that dried plum consumption significantly improved the BMD of the ulna and lumbar spine compared with the dried apple control (Figure 4) [13]. Additionally, dried plum consumption led to significantly decreased serum TRAP-5b and BALP levels. Osteocalcin and C-reactive protein levels were significantly lower in the dried plum group than in the apple group. Although the findings of our initial three-month clinical trial indicated that BALP levels increased following dried plum consumption, this was not observed in our one-year clinical trial. We cannot offer a definitive reason for this discrepancy. However, variation is inherent in bone biomarkers due to intra- and inter-individual variability, analytical reasons, and sample stability. For these reasons, BMD remains the gold-standard for evaluating bone health [43].

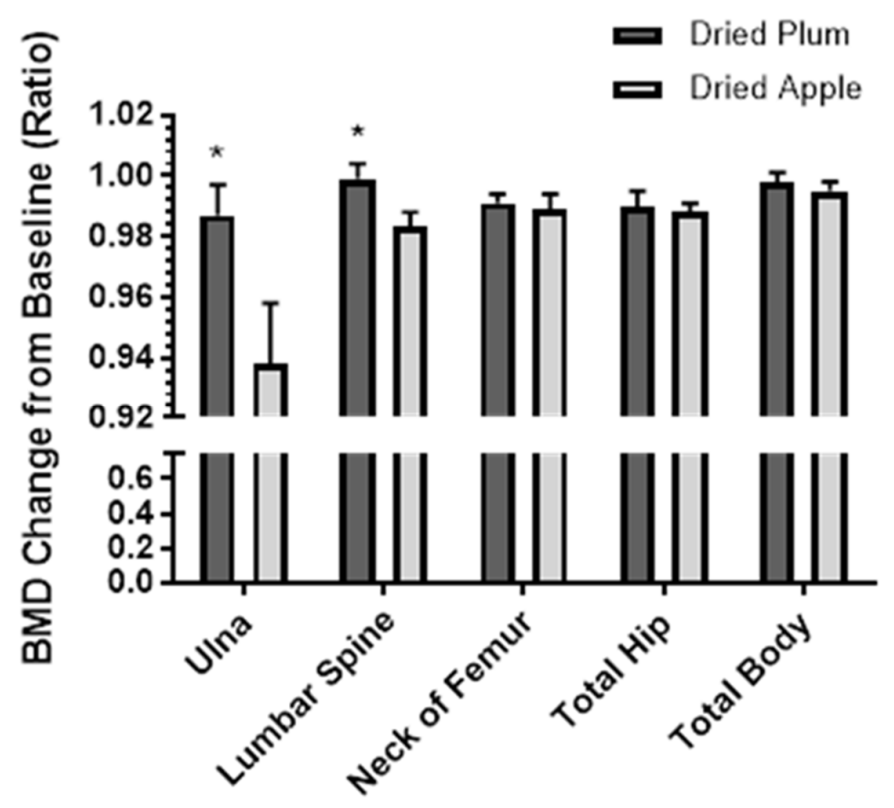

Figure 4. Change from baseline (ratio) in bone mineral density (BMD) from baseline to one-year following daily consumption of $100 \mathrm{~g}$ dried plum or $75 \mathrm{~g}$ dried apple. Bars represent mean \pm standard error of the mean. ${ }^{*}$ Denotes significant $(p<0.05)$ difference between groups.

We later investigated the potential mechanisms of action by which dried plum exerted these effects. We showed that compared to the baseline, dried plum increased receptor activator of nuclear factor kappa-B ligand levels by $+1.99 \%$ versus $+18.33 \%$ in the control group, increased the osteoprotegerin 
levels by $+4.87 \%$ versus $-2.15 \%$ in the control group, and decreased serum sclerostin levels by $-1.12 \%$ in the dried plum group versus $+3.78 \%$ in the control group [44]. While these percent changes did not reach statistical significance, they are clearly promising preliminary findings. Collectively, these findings suggest that dried plum prevents bone loss in postmenopausal women through the suppression of bone turnover.

Next, we [45] reported the findings of a six-month clinical trial evaluating the effects of resistance training with and without dried plum at a dose of $90 \mathrm{~g}$ in postmenopausal breast cancer survivors. While both groups were found to increase upper and lower body strength, no improvements were observed in the body composition or BMD. Interestingly, both groups displayed improvements in the blood biomarkers of bone turnover, with no added effect of dried plum observed.

Our successive six-month clinical trial evaluated the efficacy of two doses of dried plum (50 g versus $100 \mathrm{~g}$ ) in preventing bone loss in older postmenopausal women [46]. Our findings confirmed dried plums' ability to prevent the loss of total body BMD and indicated that a lower dose of dried plum (i.e., $50 \mathrm{~g}$ ) may be as effective as $100 \mathrm{~g}$ of dried plum. This study also demonstrated a reduction in serum TRAP-5b in both dried plum groups.

Most recently, we evaluated whether or not individuals who received the dried plum intervention in our previous one-year clinical trial conducted five years prior were able to retain BMD to a greater extent than those who received the dried apple intervention. Of the 100 women who completed the initial clinical trial, 20 came back for a follow-up visit. All participants, irrespective of group assignment, reported that they did not regularly consume dried plums. We found that individuals that received the dried plum intervention $(n=8)$ in our previous one-year clinical trial retained BMD of the ulna and lumbar spine to a greater extent than those who received the dried apple intervention $(n=12)$ (unpublished data, Figure 5). Although these findings are preliminary, they suggest that women in the dried plum group retained bone density in the lumbar spine and ulna to a greater extent than those in the dried apple group over the course of five years, even in the absence of regular dried plum consumption. These findings should be interpreted with caution as the influence of other factors including diet, physical activity, and medications have not been evaluated. Nonetheless, these findings are promising and further research is needed to evaluate the extent to which bone density is retained following the cessation of an intervention with dried plum.

(A)

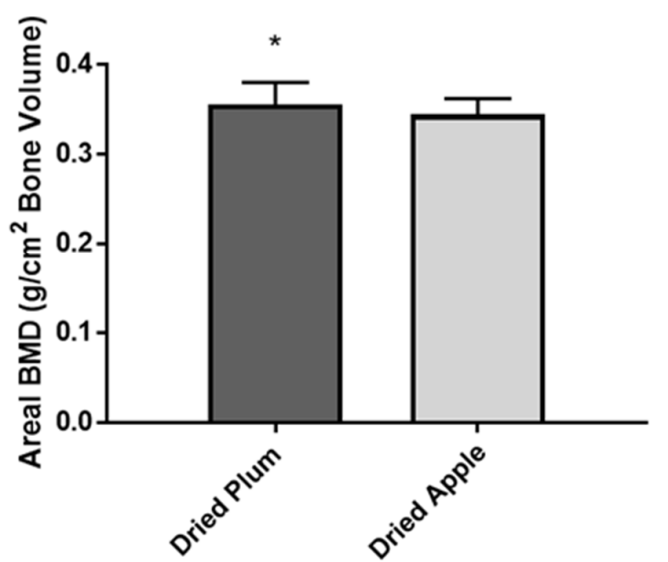

(B)

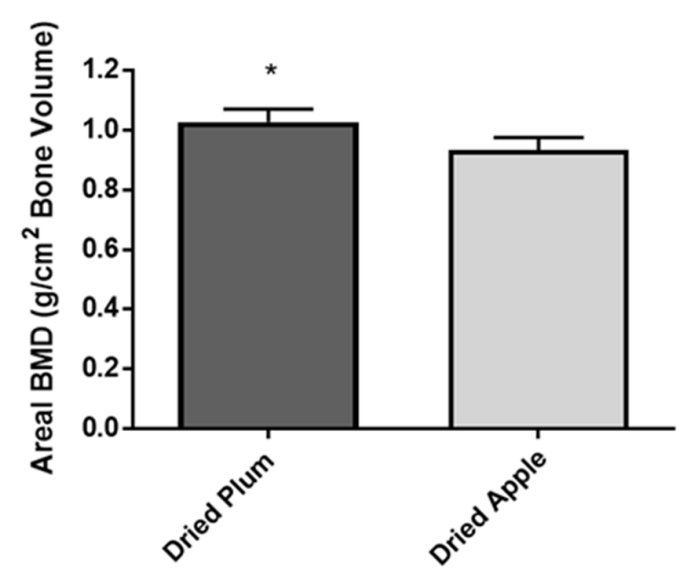

Figure 5. Bone mineral density (BMD) of the (A) ulna and (B) lumbar spine five years following one-year intervention study with daily consumption of $100 \mathrm{~g}$ dried plum or $75 \mathrm{~g}$ dried apple. Bars represent mean \pm standard error of the mean. * Values were significantly $(p<0.05)$ different between groups. 
Table 2. Clinical trials investigating the role of dried plum on bone health in postmenopausal women.

\begin{tabular}{|c|c|c|c|c|c|c|c|}
\hline Reference & Design & Population & Number & Intervention & Duration & Primary Outcomes & Primary Findings \\
\hline $\begin{array}{l}\text { Arjmandi et al., } \\
2002[41]\end{array}$ & RCT & Postmenopausal women & 58 & $\begin{array}{l}100 \mathrm{~g} / \text { day dried plum or } \\
75 \mathrm{~g} / \text { day dried apple } \\
\text { (comparative control) }\end{array}$ & 3 months & $\begin{array}{l}\text { Serum IGF-1, IGFBP-3, AP, TRAP, } \\
\text { BSAP, calcium, phosphorus, and } \\
\text { magnesium, urinary Dpd, HP, } \\
\text { and creatinine }\end{array}$ & $\begin{array}{l}\uparrow \text { IGF-1, AP, and BSAP compared } \\
\text { to baseline in dried plum group }\end{array}$ \\
\hline $\begin{array}{l}\text { Hooshmand et al., } \\
2011[13]\end{array}$ & RCT & $\begin{array}{l}\text { Postmenopausal women } \\
\text { with osteopenia }\end{array}$ & 160 & $\begin{array}{l}100 \mathrm{~g} / \text { day dried plum or } \\
75 \mathrm{~g} / \text { day dried apple } \\
\text { (comparative control) }\end{array}$ & 12 months & $\begin{array}{l}\text { Whole body, lumbar spine, hip, } \\
\text { and forearm BMD; serum BALP, } \\
\text { osteocalcin, TRAP-5b, and CRP }\end{array}$ & $\begin{array}{l}\uparrow \text { ulna and lumbar spine BMD in } \\
\text { dried plum group compared to } \\
\text { dried apple }(p<0.05), \downarrow \text { BALP in } \\
\text { dried plum group } \\
\text { compared to baseline }\end{array}$ \\
\hline $\begin{array}{l}\text { Hooshmand et al., } \\
\quad 2014[44]\end{array}$ & $\mathrm{RCT}$ & $\begin{array}{l}\text { Postmenopausal women } \\
\text { with osteopenia }\end{array}$ & 160 & $\begin{array}{l}100 \mathrm{~g} / \text { day dried plum or } \\
75 \mathrm{~g} / \text { day dried apple } \\
\text { (comparative control) }\end{array}$ & 12 months & $\begin{array}{l}\text { Serum Dpd, RANKL, OPG, } \\
\text { and sclerostin }\end{array}$ & $\begin{array}{l}\text { Non-significant } \uparrow \text { in RANKL, } \\
\text { RANKL/OPG ratio, and } \\
\text { sclerostin, and } \downarrow \text { in OPG } \\
\text { compared to baseline in dried } \\
\text { apple group, non-significant } \uparrow \text { in } \\
\text { OPG and RANKL and } \downarrow \text { in } \\
\text { sclerostin in dried plum group } \\
\text { compared to baseline }\end{array}$ \\
\hline $\begin{array}{l}\text { Simonavice et al., } \\
2014 \text { [45] }\end{array}$ & $\begin{array}{l}\text { Non-randomized } \\
\text { intervention trial }\end{array}$ & $\begin{array}{l}\text { Postmenopausal breast } \\
\text { cancer survivors }\end{array}$ & 23 & $\begin{array}{l}\text { Resistance exercise } \\
\text { with/without } 90 \mathrm{~g} / \text { day } \\
\text { dried plum }\end{array}$ & 6 months & $\begin{array}{l}\text { Whole body, lumbar spine, femur, } \\
\text { and forearm BMD; serum BAP, } \\
\text { TRAP-5b, and CRP }\end{array}$ & No significant effects \\
\hline $\begin{array}{l}\text { Hooshmand et al., } \\
2016 \text { [46] }\end{array}$ & RCT & $\begin{array}{l}\text { Older postmenopausal } \\
\text { women }\end{array}$ & 48 & $\begin{array}{l}0,50, \text { or } 100 \mathrm{~g} / \text { day } \\
\text { dried plum }\end{array}$ & 6 months & $\begin{array}{l}\text { Whole body, lumbar spine, hip, } \\
\text { and forearm BMD; serum hs-CRP, } \\
\text { IGF-1, BAP, TRAP-5b, } \\
\text { BAP/TRAP-5b ratio, sclerostin, } \\
\text { 25-OH vitamin D, RANKL, OPG, } \\
\text { calcium, and phosphorus }\end{array}$ & $\begin{array}{l}\uparrow \text { whole body BMD in both dried } \\
\text { plum groups compared to control, } \\
\downarrow \text { TRAP- } 5 \mathrm{~b} \text { at } 3 \text { and } 6 \text { months in } \\
\text { dried plum groups compared to } \\
\text { control, } \uparrow \text { BAP/TRAP-5b ratio at } \\
6 \text { months in both dried plum } \\
\text { groups compared to baseline }\end{array}$ \\
\hline
\end{tabular}




\section{Bioactive Compounds and Possible Mechanisms of Action}

Dried plum is known to contain several bioactive compounds including dietary fiber, vitamins (e.g., vitamin K), minerals (e.g., boron, copper), and (poly)phenolic compounds such as chlorogenic acids (i.e., chlorogenic acid, neochlorogenic acid, and cryptochlorogenic acid) and proanthocyanidins $[24,25]$. The exact nutrients and/or components contributing to the bone-protective effects of dried plum are unknown. However, many of these compounds are known to exert bone-protective effects and therefore likely work additively and/or synergistically.

Among the compounds found in dried plum is boron, which is a trace element critical for bone health as a deficiency or excess in consumption of boron can be harmful to bone. Dried plum contains a higher amount of boron than most fruits. In fact, the content of boron in $47.7 \mathrm{~g}$ dried plum $(\sim 5$ dried plums) is about $1.1 \mathrm{mg}$ [23]. The average daily intake of boron is about 1-2 mg/day, depending on sex and age, among other factors [47]. Boron has been shown to stimulate bone growth and bone metabolism [48], and play an important role in preserving BMD, bone microarchitecture, and bone strength [49-51]. A study by Chapin et al. [52] showed that rats fed diets containing 20 or more mg boron $/ 100 \mathrm{~g}$ diet had a significantly improved vertebral strength. These authors also demonstrated that rats fed a boric acid diet of 200 ppm or more for nine weeks not only had a significant increase in the boron content of their bone, but retained their bone boron content three-fold greater than the controls 32 weeks after exposure to the diet ended. This suggests that boron has the ability to accumulate in bone, and though the half-life of boron in bone is uncertain, it may be similar to that of calcium, where the half-life is significantly longer than in tissue. This action of boron may play a role in the maintenance of bone density over long periods of time, even without regular consumption.

Another mineral abundant in dried plum important for bone health is potassium [53,54]. One hundred grams of dried plum contains $732 \mathrm{mg}$. Tucker et al. [55] investigated both the cross-sectional and longitudinal relationships between potassium and BMD using a Framingham Heart Study database and concluded that potassium contributes to the maintenance of BMD in men and women. Additionally, higher intakes of potassium have been shown to reduce bone resorption, particularly in the face of high protein intake [56].

Dried plum is also a good source of copper. A $47.7 \mathrm{~g}$ serving of dried plum provides $0.13 \mathrm{mg}$, which is $31.2 \%$ of the dietary reference intake. Copper is a cofactor for lysyl oxidase, which is involved in the cross-linking of collagen and elastin [24,57]. In an in vivo study by Yee et al. [57], Ovx Sprague-Dawley rats placed on a copper deficient diet had more severe osteopenia than the copper adequate diet. Copper may in part contribute to the beneficial properties of dried plum on bone, giving an additive effect.

Dried plum is rich in vitamin $\mathrm{K}$ and a $47.7 \mathrm{~g}$ serving of dried plum provides $348 \mathrm{mg}$ vitamin $\mathrm{K}$, or $15.6 \%$ of the dietary reference intake [53]. Vitamin $\mathrm{K}$ is important for bone health as it promotes a calcium balance [58]. Additionally, it is a cofactor for the $\gamma$-carboxylation of osteocalcin, a bone matrix protein secreted by osteoblasts that promotes normal bone mineralization by regulating the growth of hydroxyapatite crystals [58]. A study by Braam et al. [59] demonstrated that supplementation with vitamin $\mathrm{K}$ at the level of $1 \mathrm{mg}$ daily for three years attenuated the loss of BMD in the lumbar spine.

Among the (poly)phenols found in dried plum, chlorogenic acids (e.g., neochlorogenic acid, cryptochlorigenic acid, and chlorogenic acid) are the most abundant. In fact, $100 \mathrm{~g}$ of dried plum is estimated to contain between 108 and $153 \mathrm{mg}$ chlorogenic acids. Previous research has demonstrated that chlorogenic acids are bone-protective. For instance, Zhou et al. [60] demonstrated that supplementing Ovx rats with chlorogenic acid led to improved BMD and microarchitecture, and an increased proliferation of osteoblast precursors and osteoblast differentiation, as well as increases in bone formation biomarkers. Despite this, Léotoing et al. [40] demonstrated that the bone-protective effects of dried plum is not dependent on the content of chlorogenic acids. As the authors pointed out, it is important to consider that dried plum contains other (poly)phenols such as quercetin, rutin, proanthocyanidins, among others, as well as dietary fiber in the form of soluble and insoluble fiber including pectin, fructans, hemicelluloses, and cellulose $[23,40]$, which may be 
responsible for the effects of dried plum on bone. (Poly)phenols and their metabolites are known to not only act as antioxidants themselves [53,61,62], but to also activate endogenous antioxidant and inhibit inflammatory signaling pathways [63,64]. Considering that bone loss has been linked to oxygen-derived free radicals in the bone microenvironment, an imbalance in antioxidant defenses, and oxidative stress [65,66], as well as a pro-inflammatory state [67], it is possible that other dried plum (poly)phenols and their metabolites work through this mechanism. In fact, we and others have demonstrated the antioxidant and anti-inflammatory properties of dried plum [68,69]. Dried plum has a high oxygen radical absorbance capacity (ORAC) compared with many commonly consumed fruits and vegetables [70]. More recently, Kayano et al. [61], have isolated several ortho-diphenolic and mono hydroxyl phenolic compounds with ORAC values as high as 4.68 units of Trolox equivalent per mg of dried plum. Therefore, the beneficial effects of dried plum on bone may be partly mediated through its antioxidant properties.

Importantly, dried plum is rich in soluble and insoluble fibers, including pectin, fructans, hemicelluloses, and cellulose [23,40], which are known to increase mineral absorption (e.g., calcium) [71]. For instance, fibers are fermented by colonic bacteria, resulting in the production of short-chain fatty acids (SCFA). SCFAs enhance calcium absorption through reductions in the $\mathrm{pH}$ of the intestinal lumen and increasing the solubility of calcium, thereby facilitating passive diffusion through exchanges of luminal calcium with cellular hydrogen, and increasing the permeability of gut epithelial cells and paracellular transport $[40,71,72]$. Dietary fiber, including prebiotic dietary fibers, as well as (poly)phenolic compounds, have been shown to alter the microbial composition in the gut $[71,73,74]$. As such, it is possible that chronic dried plum consumption induces changes in the gut microbiome, thereby increasing SCFA production. It is also possible that these changes in the gut microbiome promote bone health through other mechanisms including those involving the immune system. However, this has yet to be investigated and is therefore speculative.

Lastly, previous research has shown that dried plum rich in chlorogenic acid increases bone calcium retention in an Ovx rodent model of postmenopausal osteoporosis [39]. Although changes in biomarkers of bone turnover were not noted, the observation that bone calcium retention was greater is consistent with the notion that dried plum reduces bone turnover. This is an interesting finding that warrants further investigation.

\section{Conclusions}

The bone-protective effects of dried plum in postmenopausal women have been supported by several animal studies and confirmed in randomized controlled trials. The exact mechanisms by which dried plum exerts these effects remains unknown. Additionally, it is unclear as to which bioactive compound(s) in dried plum is/are responsible for its bone-protective properties. Considering that many of the bioactive compounds present in dried plum have been shown to modulate bone metabolism, it is likely that there are additive and/or synergistic effects among these compounds. In addition to preventing bone loss in postmenopausal women, our recent findings suggest that the bone-protective effects of dried plum may be long-lasting, thereby contributing to the maintenance of bone density after regular consumption has ceased.

The findings of our previously conducted clinical trials indicate that dried plum is most efficacious in preventing bone loss in the ulna and lumbar spine. Although the reason for this is not currently known, both vertebra and ulna contain more trabecular bone than other sites (e.g., femur). In fact, vertebra and ulna contain more than $60 \%$ and up to $50 \%$ trabecular bone, respectively. Bone turnover is known to be greater in trabecular bone than cortical bone $[75,76]$. The body of literature suggests that dried plum slows the rate of bone turnover. As such, it is likely that dried plum has a more pronounced effect of reducing bone loss at these sites through reductions in trabecular bone turnover.

An important point to consider with any nutritional intervention, including functional foods, is caloric intake. The addition of dried plum to the diet contributes approximately $120 \mathrm{kcal}$ and $240 \mathrm{kcal}$ for $50 \mathrm{~g}$ and $100 \mathrm{~g}$ doses, respectively [23]. In our previous clinical trials, study participants were 
advised to maintain their usual diet and physical activity patterns throughout the duration of the study. We did not observe significant changes in nutritional intake, including calories, nor in body weight. Considering that self-reported dietary intake and physical activity are known to have limitations, including measurement error, it is therefore unknown as to whether our study participants made alterations in their diets or physical activity to maintain their body weight. Dried plum is high in dietary fiber which alters the transit time and may increase satiety, thereby reducing the overall caloric intake. Logically, one would assume that the addition of dried plum to the diet would displace other calories. However, this is speculative and needs future confirmation.

Future research should aim not only to better understand the mechanisms by which dried plum consumption contributes to bone health, including the involvement of the gut microbiome, but also to elucidate the long-term maintenance of such effects, including their role in fracture prevention. With respect to feasibility, we have observed good study participant treatment compliance and retention with long-term dried plum consumption at doses of $50 \mathrm{~g}$ (six months) and $100 \mathrm{~g}$ (one year). Study participants were generally willing to commit to the regular consumption of dried plum in order to improve their bone health and avoid taking osteoporosis medications. Our study participants were educated on ways to incorporate dried plum into their diets (e.g., in their meals) in an effort to promote compliance. Nonetheless, there are challenges with any long-term dietary intervention. For this reason, it is important that future studies aim to establish the lowest dose of dried plum or alternative dosing methods (e.g., intermittent dosing regimens) that provide the same efficacy as $100 \mathrm{~g} /$ day. Additionally, the combination of other foods and/or bioactive compounds that show promise for bone health, such as FOS, with dried plum should be further investigated, as this may enhance its efficacy. Finally, many of the previously conducted clinical trials evaluating the bone-protective effects of dried plum had small sample sizes, which may have contributed to null findings. Therefore, future large-scale clinical trials are needed to further establish the bone-protective effects of dried plum in postmenopausal women.

Acknowledgments: This work was funded in part by the California Dried Plum Board and the United States Department of Agriculture.

Conflicts of Interest: The authors declare no conflict of interest.

\section{References}

1. Barrett-Connor, E. Epidemiology and the Menopause: A Global Overview. Int. J. Fertil. Menopausal. Stud. 1993, 38 (Suppl. 1), 6-14. [PubMed]

2. American Congress of Obstetricians and Gynecologists. 2011 Women's Health Stats and Facts. Available online: https:/ /www.acog.org/- /media/NewsRoom/MediaKit.pdf (accessed on 14 April 2017).

3. Facts and Statistics. International Osteoporosis Foundation. Available online: https://www.iofbonehealth. org/facts-statistics (accessed on 14 April 2017).

4. Raisz, L.G. Pathogenesis of Osteoporosis: Concepts, Conflicts, and Prospects. J. Clin. Investig. 2005, 115, 3318-3325. [CrossRef] [PubMed]

5. Kamienski, M.; Tate, D.; Vega, M. The Silent Thief: Diagnosis and Management of Osteoporosis. Orthop. Nurs. 2011, 30, 162-171. [CrossRef] [PubMed]

6. Burge, R.; Dawson-Hughes, B.; Solomon, D.H.; Wong, J.B.; King, A.; Tosteson, A. Incidence and Economic Burden of Osteoporosis-Related Fractures in the United States, 2005-2025. J. Bone Miner. Res. 2007, 22, 465-475. [CrossRef] [PubMed]

7. Looker, A.C.; Borrud, L.G.; Dawson-Hughes, B.; Shepherd, J.A.; Wright, N.C. Osteoporosis or Low Bone Mass at the Femur Neck or Lumbar Spine in Older Adults: United States, 2005-2008. NCHS Data Brief 2012, 93, 1-8.

8. Demontiero, O.; Vidal, C.; Duque, G. Aging and Bone Loss: New Insights for the Clinician. Ther. Adv. Musculoskelet. Dis. 2012, 4, 61-76. [CrossRef] [PubMed] 
9. Almeida, M.; Laurent, M.R.; Dubois, V.; Claessens, F.; O’Brien, C.A.; Bouillon, R.; Vanderschueren, D.; Manolagas, S.C. Estrogens and Androgens in Skeletal Physiology and Pathophysiology. Physiol. Rev. 2017, 97, 135-187. [CrossRef] [PubMed]

10. Rossouw, J.E.; Anderson, G.L.; Prentice, R.L.; LaCroix, A.Z.; Kooperberg, C.; Stefanick, M.L.; Jackson, R.D.; Beresford, S.A.; Howard, B.V.; Johnson, K.C.; et al. Risks and Benefits of Estrogen Plus Progestin in Healthy Postmenopausal Women: Principal Results from the Women's Health Initiative Randomized Controlled Trial. JAMA 2002, 288, 321-333. [CrossRef] [PubMed]

11. Kayser, J.; Ettinger, B.; Pressman, A. Postmenopausal Hormonal Support: Discontinuation of Raloxifene Versus Estrogen. Menopause 2001, 8, 328-332. [CrossRef] [PubMed]

12. Cashman, K.D. Diet, Nutrition, and Bone Health. J. Nutr. 2007, 137, 2507S-2512S. [PubMed]

13. Hooshmand, S.; Chai, S.C.; Saadat, R.L.; Payton, M.E.; Brummel-Smith, K.; Arjmandi, B.H. Comparative Effects of Dried Plum and Dried Apple on Bone in Postmenopausal Women. Br. J. Nutr. 2011, 106, 923-930. [CrossRef] [PubMed]

14. Arjmandi, B.H.; Johnson, C.D.; Campbell, S.C.; Hooshmand, S.; Chai, S.C.; Akhter, M.P. Combining Fructooligosaccharide and Dried Plum Has the Greatest Effect on Restoring Bone Mineral Density among Select Functional Foods and Bioactive Compounds. J. Med. Food 2010, 13, 312-319. [CrossRef] [PubMed]

15. Johnson, C.D.; Lucas, E.A.; Hooshmand, S.; Campbell, S.; Akhter, M.P.; Arjmandi, B.H. Addition of Fructooligosaccharides and Dried Plum to Soy-Based Diets Reverses Bone Loss in the Ovariectomized Rat. Evid. Based Complement. Alternat. Med. 2011, 2011, 836267. [CrossRef] [PubMed]

16. Rendina, E.; Lim, Y.F.; Marlow, D.; Wang, Y.; Clarke, S.L.; Kuvibidila, S.; Lucas, E.A.; Smith, B.J. Dietary Supplementation with Dried Plum Prevents Ovariectomy-Induced Bone Loss While Modulating the Immune Response in C57bl/6j Mice. J. Nutr. Biochem. 2012, 23, 60-68. [CrossRef] [PubMed]

17. Halloran, B.P.; Wronski, T.J.; VonHerzen, D.C.; Chu, V.; Xia, X.; Pingel, J.E.; Williams, A.A.; Smith, B.J. Dietary Dried Plum Increases Bone Mass in Adult and Aged Male Mice. J. Nutr. 2010, 140, 1781-1787. [CrossRef] [PubMed]

18. Mühlbauer, R.C.; Lozano, A.; Reinli, A. Onion and a Mixture of Vegetables, Salads, and Herbs Affect Bone Resorption in the Rat by a Mechanism Independent of Their Base Excess. J. Bone Miner. Res. 2002, 17, 1230-1236. [CrossRef] [PubMed]

19. Mühlbauer, R.C.; Lozano, A.; Reinli, A.; Wetli, H. Various Selected Vegetables, Fruits, Mushrooms and Red Wine Residue Inhibit Bone Resorption in Rats. J. Nutr. 2003, 133, 3592-3597. [PubMed]

20. Devareddy, L.; Hooshmand, S.; Collins, J.K.; Lucas, E.A.; Chai, S.C.; Arjmandi, B.H. Blueberry Prevents Bone Loss in Ovariectomized Rat Model of Postmenopausal Osteoporosis. J. Nutr. Biochem. 2008, 19, 694-699. [CrossRef] [PubMed]

21. Zhang, J.; Lazarenko, O.P.; Blackburn, M.L.; Shankar, K.; Badger, T.M.; Ronis, M.J.; Chen, J.R. Feeding Blueberry Diets in Early Life Prevent Senescence of Osteoblasts and Bone Loss in Ovariectomized Adult Female Rats. PLoS ONE 2011, 6, e24486. [CrossRef] [PubMed]

22. Zhang, J.; Lazarenko, O.P.; Blackburn, M.L.; Badger, T.M.; Ronis, M.J.; Chen, J.R. Blueberry Consumption Prevents Loss of Collagen in Bone Matrix and Inhibits Senescence Pathways in Osteoblastic Cells. Age (Dordr) 2013, 35, 807-820. [CrossRef] [PubMed]

23. Bowen, P.E. Role of Commodity Boards in Advancing the Understanding of the Health Benefits of Whole Foods: California Dried Plums. Nutr. Today 2017, 52, 19-25. [CrossRef] [PubMed]

24. Stacewicz-Sapuntzakis, M. Dried Plums and Their Products: Composition and Health Effects-An Updated Review. Crit. Rev. Food Sci. Nutr. 2013, 53, 1277-1302. [CrossRef] [PubMed]

25. Hooshmand, S.; Arjmandi, B.H. Viewpoint: Dried Plum, an Emerging Functional Food That May Effectively Improve Bone Health. Ageing Res. Rev. 2009, 8, 122-127. [CrossRef] [PubMed]

26. Horcajada-Molteni, M.N.; Crespy, V.; Coxam, V.; Davicco, M.J.; Rémésy, C.; Barlet, J.P. Rutin Inhibits Ovariectomy-Induced Osteopenia in Rats. J. Bone Miner. Res. 2000, 15, 2251-2258. [CrossRef] [PubMed]

27. Arjmandi, B.H.; Lucas, E.A.; Juma, S.; Soliman, A.; Stoecker, B.J.; Khalil, D.A.; Smith, B.J.; Wang, C. Prune Prevents Ovariectomy-Induced Bone Loss in Rats. J. Am. Nutraceutical Assoc. 2001, 4, 50-56.

28. Kalu, D.N. The Ovariectomized Rat Model of Postmenopausal Bone Loss. Bone Miner. 1991, 15, $175-191$. [CrossRef] 
29. Lane, N.E.; Haupt, D.; Kimmel, D.B.; Modin, G.; Kinney, J.H. Early Estrogen Replacement Therapy Reverses the Rapid Loss of Trabecular Bone Volume and Prevents Further Deterioration of Connectivity in the Rat. J. Bone Miner. Res. 1999, 14, 206-214. [CrossRef] [PubMed]

30. Tokunaga, T. Novel Physiological Function of Fructooligosaccharides. Biofactors 2004, 21, 89-94. [CrossRef] [PubMed]

31. Devareddy, L.; Khalil, D.A.; Korlagunta, K.; Hooshmand, S.; Bellmer, D.D.; Arjmandi, B.H. The Effects of Fructo-Oligosaccharides in Combination with Soy Protein on Bone in Osteopenic Ovariectomized Rats. Menopause 2006, 13, 692-699. [CrossRef] [PubMed]

32. Devareddy, L.; Khalil, D.A.; Smith, B.J.; Lucas, E.A.; Soung, D.Y.; Marlow, D.D.; Arjmandi, B.H. Soy Moderately Improves Microstructural Properties without Affecting Bone Mass in an Ovariectomized Rat Model of Osteoporosis. Bone 2006, 38, 686-693. [CrossRef] [PubMed]

33. Arjmandi, B.H.; Lucas, E.A.; Khalil, D.A.; Devareddy, L.; Smith, B.J.; McDonald, J.; Arquitt, A.B.; Payton, M.E.; Mason, C. One Year Soy Protein Supplementation Has Positive Effects on Bone Formation Markers but Not Bone Density in Postmenopausal Women. Nutr. J. 2005, 4, 8. [CrossRef] [PubMed]

34. Arjmandi, B.H.; Khalil, D.A.; Smith, B.J.; Lucas, E.A.; Juma, S.; Payton, M.E.; Wild, R.A. Soy Protein Has a Greater Effect on Bone in Postmenopausal Women Not on Hormone Replacement Therapy, as Evidenced by Reducing Bone Resorption and Urinary Calcium Excretion. J. Clin. Endocrinol. Metab. 2003, 88, 1048-1054. [CrossRef] [PubMed]

35. Arjmandi, B.H.; Birnbaum, R.; Goyal, N.V.; Getlinger, M.J.; Juma, S.; Alekel, L.; Hasler, C.M.; Drum, M.L.; Hollis, B.W.; Kukreja, S.C. Bone-Sparing Effect of Soy Protein in Ovarian Hormone-Deficient Rats Is Related to Its Isoflavone Content. Am. J. Clin. Nutr. 1998, 68, 1364S-1368S. [PubMed]

36. Rendina, E.; Hembree, K.D.; Davis, M.R.; Marlow, D.; Clarke, S.L.; Halloran, B.P.; Lucas, E.A.; Smith, B.J. Dried Plum's Unique Capacity to Reverse Bone Loss and Alter Bone Metabolism in Postmenopausal Osteoporosis Model. PLoS ONE 2013, 8, e60569. [CrossRef] [PubMed]

37. Smith, B.J.; Bu, S.Y.; Wang, Y.; Rendina, E.; Lim, Y.F.; Marlow, D.; Clarke, S.L.; Cullen, D.M.; Lucas, E.A. A Comparative Study of the Bone Metabolic Response to Dried Plum Supplementation and Pth Treatment in Adult, Osteopenic Ovariectomized Rat. Bone 2014, 58, 151-159. [CrossRef] [PubMed]

38. Deyhim, F.; Stoecker, B.J.; Brusewitz, G.H.; Devareddy, L.; Arjmandi, B.H. Dried Plum Reverses Bone Loss in an Osteopenic Rat Model of Osteoporosis. Menopause 2005, 12, 755-762. [CrossRef] [PubMed]

39. Pawlowski, J.W.; Martin, B.R.; McCabe, G.P.; Ferruzzi, M.G.; Weaver, C.M. Plum and Soy Aglycon Extracts Superior at Increasing Bone Calcium Retention in Ovariectomized Sprague Dawley Rats. J. Agric. Food Chem. 2014, 62, 6108-6117. [CrossRef] [PubMed]

40. Leotoing, L.; Wauquier, F.; Davicco, M.J.; Lebecque, P.; Gaudout, D.; Rey, S.; Vitrac, X.; Massenat, L.; Rashidi, S.; Wittrant, Y.; et al. The Phenolic Acids of Agen Prunes (Dried Plums) or Agen Prune Juice Concentrates Do Not Account for the Protective Action on Bone in a Rat Model of Postmenopausal Osteoporosis. Nutr. Res. 2016, 36, 161-173. [CrossRef] [PubMed]

41. Arjmandi, B.H.; Khalil, D.A.; Lucas, E.A.; Georgis, A.; Stoecker, B.J.; Hardin, C.; Payton, M.E.; Wild, R.A. Dried Plums Improve Indices of Bone Formation in Postmenopausal Women. J. Womens Health Gend. Based Med. 2002, 11, 61-68. [CrossRef] [PubMed]

42. Hodsman, A.B.; Fraher, L.J.; Watson, P.H.; Ostbye, T.; Stitt, L.W.; Adachi, J.D.; Taves, D.H.; Drost, D. A Randomized Controlled Trial to Compare the Efficacy of Cyclical Parathyroid Hormone Versus Cyclical Parathyroid Hormone and Sequential Calcitonin to Improve Bone Mass in Postmenopausal Women with Osteoporosis. J. Clin. Endocrinol. Metab. 1997, 82, 620-628. [CrossRef] [PubMed]

43. Wheater, G.; Elshahaly, M.; Tuck, S.P.; Datta, H.K.; van Laar, J.M. The Clinical Utility of Bone Marker Measurements in Osteoporosis. J. Transl. Med. 2013, 11, 201. [CrossRef] [PubMed]

44. Hooshmand, S.; Brisco, J.R.; Arjmandi, B.H. The Effect of Dried Plum on Serum Levels of Receptor Activator of Nf-Kappab Ligand, Osteoprotegerin and Sclerostin in Osteopenic Postmenopausal Women: A Randomised Controlled Trial. Br. J. Nutr. 2014, 112, 55-60. [CrossRef] [PubMed]

45. Simonavice, E.; Liu, P.Y.; Ilich, J.Z.; Kim, J.S.; Arjmandi, B.; Panton, L.B. The Effects of a 6-Month Resistance Training and Dried Plum Consumption Intervention on Strength, Body Composition, Blood Markers of Bone Turnover, and Inflammation in Breast Cancer Survivors. Appl. Physiol. Nutr. Metab. 2014, 39, 730-739. [CrossRef] [PubMed] 
46. Hooshmand, S.; Kern, M.; Metti, D.; Shamloufard, P.; Chai, S.C.; Johnson, S.A.; Payton, M.E.; Arjmandi, B.H. The Effect of Two Doses of Dried Plum on Bone Density and Bone Biomarkers in Osteopenic Postmenopausal Women: A Randomized, Controlled Trial. Osteoporos. Int. 2016, 27, 2271-2279. [CrossRef] [PubMed]

47. Trumbo, P.; Yates, A.A.; Schlicker, S.; Poos, M. Dietary Reference Intakes: Vitamin A, Vitamin K, Arsenic, Boron, Chromium, Copper, Iodine, Iron, Manganese, Molybdenum, Nickel, Silicon, Vanadium, and Zinc. J. Am. Diet. Assoc. 2001, 101, 294-301. [CrossRef]

48. Nielsen, F.H.; Hunt, C.D.; Mullen, L.M.; Hunt, J.R. Effect of Dietary Boron on Mineral, Estrogen, and Testosterone Metabolism in Postmenopausal Women. FASEB J. 1987, 1, 394-397. [CrossRef]

49. Nielsen, F.H. Biochemical and Physiologic Consequences of Boron Deprivation in Humans. Environ. Health Perspect. 1994, 102 (Suppl. 7), 59-63. [CrossRef] [PubMed]

50. Nielsen, F.H. Is Boron Nutritionally Relevant? Nutr. Rev. 2008, 66, 183-191. [CrossRef] [PubMed]

51. Zofkova, I.; Davis, M.; Blahos, J. Trace Elements Have Beneficial, as Well as Detrimental Effects on Bone Homeostasis. In Physiol. Res.; 2017. Available online: https://www.ncbi.nlm.nih.gov/pubmed/28248532 (accessed on 14 April 2017).

52. Chapin, R.E.; Ku, W.W.; Kenney, M.A.; McCoy, H. The Effects of Dietary Boric Acid on Bone Strength in Rats. Biol. Trace Elem. Res. 1998, 66, 395-399. [CrossRef] [PubMed]

53. Dismore, M.L.; Haytowitz, D.B.; Gebhardt, S.E.; Peterson, J.W.; Booth, S.L. Vitamin K Content of Nuts and Fruits in the US Diet. J. Am. Diet. Assoc. 2003, 103, 1650-1652. [CrossRef] [PubMed]

54. Stacewicz-Sapuntzakis, M.; Bowen, P.E.; Hussain, E.A.; Damayanti-Wood, B.I.; Farnsworth, N.R. Chemical Composition and Potential Health Effects of Prunes: A Functional Food? Crit. Rev. Food Sci. Nutr. 2001, 41, 251-286. [CrossRef] [PubMed]

55. Tucker, K.L.; Hannan, M.T.; Chen, H.; Cupples, L.A.; Wilson, P.W.; Kiel, D.P. Potassium, Magnesium, and Fruit and Vegetable Intakes Are Associated with Greater Bone Mineral Density in Elderly Men and Women. Am. J. Clin. Nutr. 1999, 69, 727-736. [PubMed]

56. Zwart, S.R.; Hargens, A.R.; Smith, S.M. The Ratio of Animal Protein Intake to Potassium Intake Is a Predictor of Bone Resorption in Space Flight Analogues and in Ambulatory Subjects. Am. J. Clin. Nutr. 2004, 80, 1058-1065. [PubMed]

57. Yee, C.D.; Kubena, K.S.; Walker, M.; Champney, T.H.; Sampson, H.W. The Relationship of Nutritional Copper to the Development of Postmenopausal Osteoporosis in Rats. Biol. Trace Elem. Res. 1995, 48, 1-11. [CrossRef] [PubMed]

58. Iwamoto, J.; Takeda, T.; Sato, Y. Effects of Vitamin K2 on Osteoporosis. Curr. Pharm. Des. 2004, 10, $2557-2576$. [CrossRef] [PubMed]

59. Braam, L.A.; Knapen, M.H.; Geusens, P.; Brouns, F.; Hamulyák, K.; Gerichhausen, M.J.; Vermeer, C. Vitamin K1 Supplementation Retards Bone Loss in Postmenopausal Women between 50 and 60 Years of Age. Calcif. Tissue Int. 2003, 73, 21-26. [CrossRef] [PubMed]

60. Zhou, R.P.; Lin, S.J.; Wan, W.B.; Zuo, H.L.; Yao, F.F.; Ruan, H.B.; Xu, J.; Song, W.; Zhou, Y.C.; Wen, S.Y.; et al. Chlorogenic Acid Prevents Osteoporosis by Shp2/Pi3k/Akt Pathway in Ovariectomized Rats. PLoS ONE 2016, 11, e0166751. [CrossRef] [PubMed]

61. Kayano, S.; Kikuzaki, H.; Fukutsuka, N.; Mitani, T.; Nakatani, N. Antioxidant Activity of Prune (Prunus domestica L.) Constituents and a New Synergist. J. Agric. Food Chem. 2002, 50, 3708-3712. [CrossRef] [PubMed]

62. Nakatani, N.; Kayano, S.; Kikuzaki, H.; Sumino, K.; Katagiri, K.; Mitani, T. Identification, Quantitative Determination, and Antioxidative Activities of Chlorogenic Acid Isomers in Prune (Prunus domestica L.). J. Agric. Food Chem. 2000, 48, 5512-5516. [CrossRef] [PubMed]

63. Rahman, I.; Biswas, S.K.; Kirkham, P.A. Regulation of Inflammation and Redox Signaling by Dietary Polyphenols. Biochem. Pharmacol. 2006, 72, 1439-1452. [CrossRef] [PubMed]

64. Stevenson, D.E.; Hurst, R.D. Polyphenolic Phytochemicals-Just Antioxidants or Much More? Cell Mol. Life Sci. 2007, 64, 2900-2916. [CrossRef] [PubMed]

65. Garrett, I.R.; Boyce, B.F.; Oreffo, R.O.; Bonewald, L.; Poser, J.; Mundy, G.R. Oxygen-Derived Free Radicals Stimulate Osteoclastic Bone Resorption in Rodent Bone in Vitro and in Vivo. J. Clin. Investig. 1990, 85, 632-639. [CrossRef] [PubMed]

66. Callaway, D.A.; Jiang, J.X. Reactive Oxygen Species and Oxidative Stress in Osteoclastogenesis, Skeletal Aging and Bone Diseases. J. Bone Miner. Metab. 2015, 33, 359-370. [CrossRef] [PubMed] 
67. Mundy, G.R. Osteoporosis and Inflammation. Nutr. Rev. 2007, 65, S147-S151. [CrossRef] [PubMed]

68. Igwe, E.O.; Charlton, K.E. A Systematic Review on the Health Effects of Plums (Prunus Domestica and Prunus Salicina). Phytother. Res. 2016, 30, 701-731. [CrossRef] [PubMed]

69. Hooshmand, S.; Kumar, A.; Zhang, J.Y.; Johnson, S.A.; Chai, S.C.; Arjmandi, B.H. Evidence for Anti-Inflammatory and Antioxidative Properties of Dried Plum Polyphenols in Macrophage Raw 264.7 Cells. Food Funct. 2015, 6, 1719-1725. [CrossRef] [PubMed]

70. McBride, J. Can Foods Forestall Aging? Agric. Res. 1999, 47, 14-17.

71. McCabe, L.; Britton, R.A.; Parameswaran, N. Prebiotic and Probiotic Regulation of Bone Health: Role of the Intestine and Its Microbiome. Curr. Osteoporos. Rep. 2015, 13, 363-371. [CrossRef] [PubMed]

72. Steves, C.J.; Bird, S.; Williams, F.M.; Spector, T.D. The Microbiome and Musculoskeletal Conditions of Aging: A Review of Evidence for Impact and Potential Therapeutics. J. Bone Miner. Res. 2016, 31, 261-269. [CrossRef] [PubMed]

73. Duda-Chodak, A.; Tarko, T.; Satora, P.; Sroka, P. Interaction of Dietary Compounds, Especially Polyphenols, with the Intestinal Microbiota: A Review. Eur. J. Nutr. 2015, 54, 325-341. [CrossRef] [PubMed]

74. Tuohy, K.M.; Conterno, L.; Gasperotti, M.; Viola, R. Up-Regulating the Human Intestinal Microbiome Using Whole Plant Foods, Polyphenols, and/or Fiber. J. Agric. Food Chem. 2012, 60, 8776-8782. [CrossRef] [PubMed]

75. Clarke, B. Normal Bone Anatomy and Physiology. Clin. J. Am. Soc. Nephrol. 2008, 3 (Suppl. 3), S131-S139. [CrossRef] [PubMed]

76. Lespessailles, E.; Hambli, R.; Ferrari, S. Osteoporosis Drug Effects on Cortical and Trabecular Bone Microstructure: A Review of Hr-Pqct Analyses. Bonekey Rep. 2016, 5, 836. [CrossRef] [PubMed]

(C) 2017 by the authors. Licensee MDPI, Basel, Switzerland. This article is an open access article distributed under the terms and conditions of the Creative Commons Attribution (CC BY) license (http://creativecommons.org/licenses/by/4.0/). 